\title{
HUBUNGAN ANTARA GIZI KURANG PADA IBU SELAMA KEHAMILAN DENGAN KEJADIAN BBLR DI RUMAH SAKIT UMUM ABDUL WAHAB SYAHRENIE SAMARINDA TAHUN 2017
}

\author{
${ }^{1}$ Rr. Nindya Mayangsari ${ }^{2}$ Annisa Ul Mutmainnah ${ }^{3}$ Dian Puspita Reni \\ ${ }^{1}$ Akademi Kebidanan Mutiara Mahakam
${ }^{2}$ Akademi Kebidanan Mutiara Mahakam
${ }^{3}$ Akademi Kebidanan Mutiara Mahakam
}

\begin{abstract}
Abstrak
Pemenuhan gizi selama kehamilan sangat penting, karena apabila seorang ibu hamil mengalami kurangnya asupan gizi maka hal tersebut bisa mempengaruhi pertumbuhan janin yang ada dalam kandungannya, salah satunya adalah bayi lahir dengan berat badan rendah, baik itu kelahiran preterm (prematur) atau cukup bulan namun beratnya tidak sesuai dengan masa kehamilan. Penelitian ini bertujuan untuk mengetahui seberapa besar angka kejadian BBLR dengan dipengaruhi kurang gizi pada Ibu selama kehamilannya di RSUD Abdul Wahab Syahranie Samarinda tahun 2017. Penelitian ini menggunakan metode penelitian analitik karena menganalisis dinamika korelasi antara variabel bebas dan variabel terikat. Model pendekatan yang digunakan pada penelitian ini adalah pendekatan cross sectional dimana subjek penelitian dikumpulkan dengan cara pendekatan atau pengumpulan data sekaligus pada waktu yang bersamaan atau pada suatu saat.Berdasarkan hasil penelitian, peneliti menemukan hubungan antara gizi kurang pada ibu selama kehamilan dengan kejadian BBLR di RSUD AWS Samarinda di bulan Januari 2017, dengan presentasi cukup besar, yaitu dari 40 bayi yang lahir dengan berat badan $<2500$ gram, ada 26 bayi yang dilahirkan oleh ibu yang mengalami gizi kurang selama kehamilan.
\end{abstract}

Kata kunci : Bayi Berat Lahir Rendah, Gizi Kurang

\begin{abstract}
Nutrition fullfillment during pregnancy is very important. Pregnant mother with malnutrition will affect fetus and eventually causing low weight infant, either premature or sufficient months but infant weight is low. This research aims to discover the scale of low weight infant related to malnutrition of mother during pregnancy at Abdul Wahab Syahranie General Hospital Samarinda 2017. This research using analytical research method to analyze the correlation between independent variable and dependent variable. The researcher also use cross sectional approach where subjects are collected and using the approachment at once or at anytime. According to the research conclusion, there is a big presence of correlation between malnutrition mother during pregnancy and low weight infant at the Abdul Wahab Sjahranie General Hospital. There are 40 newborn infants with weight $<2500$ gram, there are 26 newborn infant given birth by malnutrition mothers during their pregnancy.
\end{abstract}


Keywords : low weight infat, malnutrition

\section{PENDAHULUAN}

Bayi lahir dengan berat badan rendah (BBLR) ditandai dengan berat lahir yang kurang dari 2500 gram. Kejadian BBLR pada dasarnya dihubungkan denagn kurangnya pemenuhan gizi pada ibu saat hamil, namun BBLR juga dapat terjadi karena faktor-faktor lain seperti paritas ibu, jarak kehamilan, genetik, aktivitas ibu, kadar hemoglobin dan pemanfaatan pelayanan antenatal, kehamilan ganda dan lain-lain (Yasmin dkk, 2010).

Gizi kurang pada ibu hamil adalah keadaan seorang ibu mengalami kekurangan pemenuhan gizi selama kehamilannya, hal tersebut bisa karena keadaan ekonomi ibu, pekerjaannya atau karena adanya gangguangangguan kesehatan lainnya, misalnya ibu mengalami mual-muntah yang berlebihan atau ibu tidak nafsu makan, atau bisa juga disebabkan oleh psikologi ibu, kurangnya dukungan dari keluarga dan tenaga kesehatan. Oleh sebab itu seorang ibu hamil harus tahu dan aktif dalam melakukan pemeriksaan selama kehamilan (Antenatal Care) (Yasmin dkk, 2010).

Prevalensi bayi berat lahir rendah (BBLR) menurut WHO pada tahun 2011 diperkirakan $15 \%$ dari seluruh kelahiran di dunia dengan batasan antara 3,3-38\% dan lebih sering terjadi di negara-negara berkembang atau negara dengan sosioekonomi rendah. Secara statistik angka kejadian BBLR di negara berkembang 35 kali lebih tinggi dibandingkan dengan bayi yang lahir dengan berat badan normal atau di atas 2500 gram (Marmi dkk, 2013).
BBLR berkaitan dengan kematian bayi dan balita, juga dapat berdampak serius pada kualitas generasi mendatang, yaitu akan memperlambat pertumbuhan dan perkembangan anak, serta berpengaruh pada kecerdasan anak (Depkes RI, 2010).

Rumah Sakit Umum Daerah Abdul Wahab Syahranie merupakan salah satu UPT Dinas Kesehatan Kota Samarinda, adapun alasan memilih Rumah Sakit AWS karena rumah sakit tersebut melakukan pelayanan kesehatan ibu dan anak yang merupakan salah satu rumah sakit rujukan untuk kasuskasus obstetrik dan angka kejadian bayi dengan berat badan lahir rendah dalam beberapa tahun ini masih cukup tinggi. Berdasarkan laporan tahunan kegiatan pelayanan di RSUD AWS Samarinda angka prevalensi tahun 2011-2014 cukup tinggi yaitu pada tahun 2011 ada $188(8,8 \%)$ kasus BBLR dari 2116 kelahiran hidup, menurun pada tahun 2012 yaitu $180(8 \%)$ kasus BBLR dari 2373 kelahiran hidup, lalu meningkat pada tahun 2013 yaitu $211(8,45 \%)$ kasus BBLR dari 2496 kelahiran hidup, dan mengalami peningkatan juga pada tahun 2014 yaitu 340 (12\%) kasus BBLR dari 2884 kelahiran hidup. Dari data tersebut terlihat bahwa selama kurun waktu waktu 4 tahun memperlihatkan adanya masalah BBLR di RSUD AWS Samarinda (Laporan Tahunan RSUD AWS, 2014).

Adapun penelitian dilakukan di Medical Record RSUD AWS, karena peneliti mengumpulkan data sekunder saja, yang dilakukan terhadap 68 responden. 
Berdasarkan uraian di atas peneliti sangat tertarik untuk melakukan penelitian tentang kejadian BBLR pada bayi yang dihubungkan dengan Gizi Kurang pada Ibu selama kehamilan. Oleh karena itu peneliti memilih judul "Hubungan Antara Gizi Kurang Pada Ibu Selama Kehamilan Dengan Kejadian BBLR di Rumah Sakit Umum Abdul Wahab Syahranie Samarinda pada bulan Januari tahun 2017’.

\section{METODE PENELITIAN}

Penelitian ini menggunakan metode penelitian analitik karena menganalisis dinamika korelasi antara variabel bebas dan variabel terikat. Model pendekatan yang digunakan pada penelitian ini adalah pendekatan cross sectional dimana subjek penelitian dikumpulkan dengan cara pendekatan atau pengumpulan data sekaligus pada waktu yang bersamaan atau pada suatu saat.

1. Variabel Penelitian

a. Variabel Independent (variabel bebas) dalam penelitian ini adalah gizi kurang pada ibu selama kehamilan di RSUD AWS Samarinda tahun 2017.

b. Variabel Independent (variabel bebas) dalam penelitian ini adalah gizi kurang pada ibu selama kehamilan di RSUD AWS Samarinda tahun 2017.

2. Statistika Deskriptif (Univariate)

Analisis ini menjelaskan atau mendeskripsikan angka atau nilai jumlah variabel dengan ukuran proposal atau presentasi dengan menggunakan rumus :

$$
\mathrm{P}=\frac{F}{N} \times 100 \%
$$

Keterangan :

P : Presentasi yang dicari

F : Frekuensi responden untuk setiap kategori

$\mathrm{N}$ : Jumlah responden

Analisis data statistika deskriptif dalam penelitian ini akan disajikan dalam bentuk tabel distribusi frekuensi. Kemudian akan dihitung nilai rata-rata, variansi dan simpangan baku dari data tersebut, dengan rumus :

a. Rata-rata (mean)

$$
\mathrm{X}=\frac{x_{1+} x_{2 \ldots \ldots \ldots} x_{n}}{n}
$$

b. Variansi $\left(S^{2}\right)$

$$
\mathrm{s}^{2}=\frac{n \sum x^{2}-\left(\sum x_{i}\right)^{2}}{n(n-1)}
$$

c. Simpangan baku $(\mathrm{S})$ :

$$
\mathrm{S}=\sqrt{S^{2}}
$$

3. Statistika Inferensial (Bivariate)

Analisis bivariat apabila telah dilakukan analisis univariat tersebut di atas hasilnya akan diketahui hubungan atau distribusi setiap variabel dan dapat dilanjutkan analisis bivariat (Notoatmodjo, 2010).

Analisis bivariat yang dilakukan terhadap dua variabel yang diduga berhubungan atau berkorelasi. Analisis data yang digunakan uji statistik "Chi Square" dimana analisis data dilakukan sistem komputerisasi.

Chi Square test dengan rumus :

$$
\mathrm{X}^{2}=\left\lfloor\frac{\sum\left(f_{0-f_{h}}\right)^{2}}{f_{h}}\right\rfloor
$$

Keterangan : 
$X^{2}$ : besarnya Chi Square

$f_{0}$ : frekuensi yang diperoleh untuk

setiap kategori

fh : frekuensi yang diharapkan

Untuk melihat adanya korelasi dilakukan dengan membandingkan harga $\mathrm{X}^{2}$ hitung dengan $\mathrm{X}^{2}$ tabel. Jika $\mathrm{X}^{2}$ hitung lebih besar dari $\mathrm{X}^{2}$ tabel pada taraf kesalahan tertentu. Ketentuan pengujian kalau harga $X^{2}$ hitung $>X^{2}$ tabel, ada hubungan signitif (Alimul dkk, 2010).

\section{HASIL PENELITIAN}

1. Analisis Universal

Penelitian ini dilakukan terhadap 68 responden.

a. Gizi Kurang pada ibu hamil adalah kondisi ibu mengalami kekuarangan zat gizi tertentu baik zat gizi makro maupun mikro selama kehamilannya.

Ada beberapa penyebab kurang gizi pada ibu hamil, di antaranya adalah:

1) Faktor ekonomi keluarga (kelas menengah kebawah)

2) Pola atau kebiasaan makan ibu

3) Pengetahuan ibu

4) Sosial budaya

5) Penyakit yang diderita oleh ibu

Untuk mengetahui seorang ibu mengalami gizi kurang atau tidak adalah dengan pengukuran antropometri (berat badan, tinggi badan dan LILA), dan pengukuraan Biokimia (Hemoglobin).

Dari data yang diperoleh melalui penelitian di Medical Record diketahui rata- rata untuk berat badan ibu yang bersalin di RSUD AWS bulan Januari adalah $64,1 \mathrm{~kg}$, dan rata-rata LILA adalah 29,6 cm serta nilai rata-rata $\mathrm{Hb}$ adalah $10,3 \mathrm{gr} / \mathrm{dl}$.

Dari nilai rata-rata tersebut maka status gizi ibu yang melahirkan di RSUD AWS Samarinda pada bulan Januari mengalami kekurangan zat gizi mikro.

Hasil penelitian yang dilakukan pada bulan Januari 2017 terhadap ibu yang bersalin di RSUD AWS yang berjumlah 68 responden, penilaian status gizinya adalah sebagai berikut :

Tabel 4.2 Distribusi Frekuensi Ibu Bersalin dinilai dari status gizi

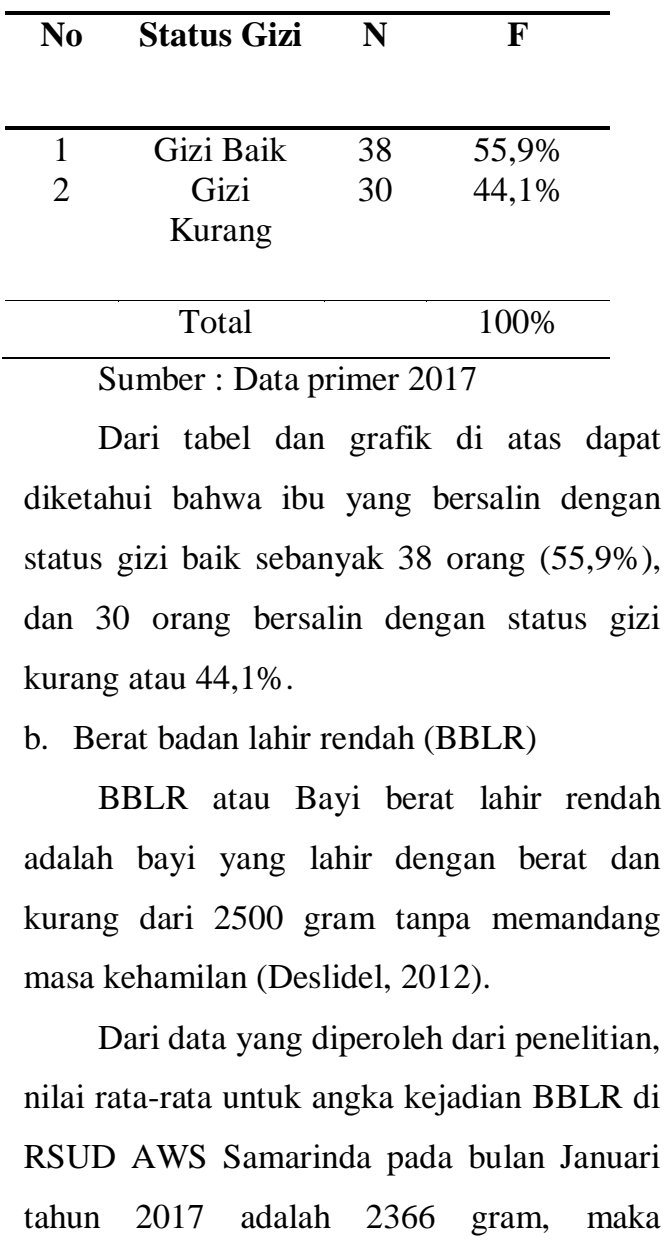


disimpulkan bahwa bayi yang lahir di bulan Januari tahun 2017 termasuk kategori BBLR.

Hasil penelitian terhadap berat badan bayi baru lahir pada bulan Januari tahun 2017 di RSUD AWS adalah sebagai berikut :

Tabel 4.3 Distribusi Frekuensi BBLR

\begin{tabular}{|c|c|c|c|}
\hline No & $\begin{array}{l}\text { Berat } \\
\text { Badan }\end{array}$ & $\mathbf{N}$ & $\mathbf{F}$ \\
\hline 1 & $\overline{B B L R}$ & 40 & 58 , \\
\hline 2 & Normal & 28 & $\begin{array}{l}8 \% \\
41, \\
2 \%\end{array}$ \\
\hline Total & & 68 & $\begin{array}{c}100 \\
\%\end{array}$ \\
\hline
\end{tabular}

Sumber : Data Sekunder (2017)

Dari tabel dan grafik di atas diketahui jumlah bayi yang lahir dengan berat badan $<2500$ gram sebanyak $40(58,8 \%)$ dan yang lahir dengan berat badan normal sebanyak 28 $(41,2 \%)$.

\section{Analisis Bivariate}

Analisis Bivariate dilakukan karena analisis Univariate telah dilakukan terlebih dahulu, analisis Bivariate dilakukan dengan menggunakan rumus Chi Square a $(0,05)$, jika $P$ value, $(0,05)$ maka menghasilkan hubungan yang bermakna antara variabel bebas dan variabel terikat.

Penelitian ini dilakukan terhadap 68 responden dimana status gizi dibagi menjadi gizi baik (pengukuran antropometri dan biokomia normal) dan gizi kurang (pengukuran antropometri dan biokimia tidak normal). Sedangkan BBLR dibagi menjadi BBLR bila berat badan lahir <2500 gram, dan Normal bila berat badan di atas 2500 gram.
Tabel 4.4 Distribusi Silang antara status gizi ibu dengan BBLR

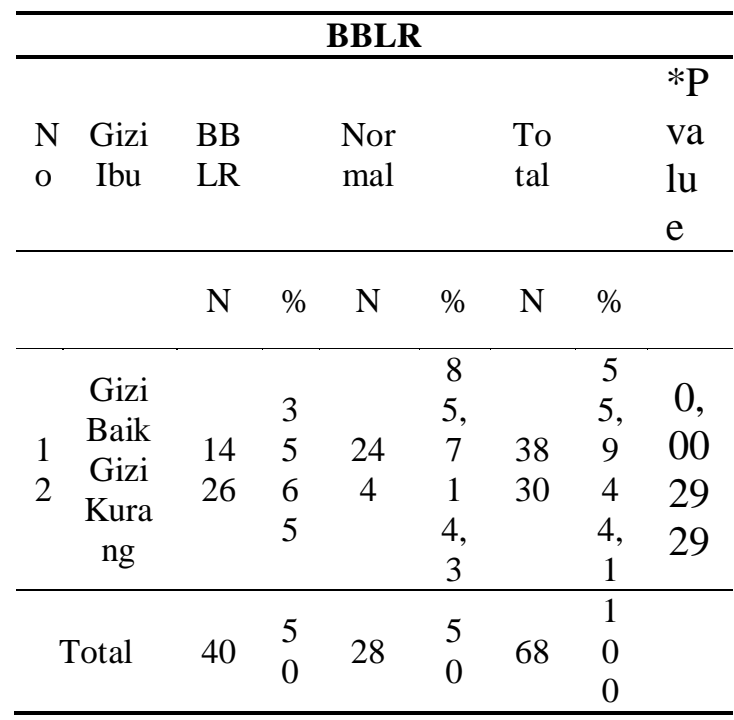

*chi square

Berdasarkan tabel diatas, diketahui nilai $\mathrm{P}<\alpha(0,003<0,05)$ maka H0 di tolak, artinya ada hubungan yang signifikan antara gizi kurang pada ibu selama kehamilan dengan kejadian BBLR di RSUD AW. Sjahranie Samarinda pada bulan Januari tahun 2017.

\section{PEMBAHASAN}

1. Univariat

a. Gizi kurang pada ibu

Dari hasil penelitian yang dilakukan di RSUD AWS pada bulan Januari 2017 terhadap 68 responden, diketahui ada 30 $(44,1 \%)$ ibu yang mengalami gizi kurang.

Selama kehamiln seorang ibu harus memiliki cukup nutrisi, karena pada masa hamil nutrisi itu bukan hanya unyuk ibu, namun juga digunakan untuk janin (Marmi $\mathrm{dkk}, 2013)$.

Sedangkan menurut hasil penelitian Elvan (2006), usia ibu juga berpengaruh terhadap kelahiran BBLR, karena jika 
seorang ibu hamil pada usia $<20$ tahun atau > 35 tahun juga mempengaruhi status gizi pada ibu tersebut, kebanyakan ibu di umur resiko tinggi mengalami gizi kurang.

Menurut peneliti, ibu yang bersalin di RSUD AWS periode bulan Januari rata-rata mengalami gizi kurang selama kehamilannya, hal tersebut dapat dilihat dari rata-rata $\mathrm{Hb}$ yang dibawah normal yaitu 10,3 gr/dl, yang menunjukkan bahwa ibu yang bersalin di RSUD AWS pada bulan Januari menderita kekurangan zat gizi mikro.

b. Kejadian BBLR

Kejadian BBLR sepanjang bulan Januari 2017 di RSUD AWS adalah sebanyak 40 bayi dari 68 bayi yang lahir, atau sebanyak $58,8 \%$.

Menurut data tahunan RSUD AWS (2014), kejadian BBLR di RSUD AWS tiap tahun memang mengalami peningkatan. Dari 4 tahun terakhir peningkatan paling signifikan terjadi pada tahun 2014, yaitu sebanyak $12 \%$.

penyebab utama BBLR adalah masalah gizi pada ibunya. Sedangkan menurut hasil penelitian Elvan (2006), kejadian BBLR berhubungan dengan usia ibu yang merupakan faktor utama dari kekurangan gizi pada ibu selama kehamilannya.

Menurut peneliti, penyebab kelahiran BBLR sepanjang bulan Januari 2017 adalah Gizi kurang pada ibu selama kehamilannya. Hal ini dapat dilihat dari hasil penelitian yang menunjukkan bahwa hampir seluruh ibu yang mengalami gizi kurang telah melahirkan bayi dengan berat badan $<2500$ gram.

\section{Bivariat}

Hasil analisis bivariate didapatkan responden ibu dngan status gizi kurang yang melahirkan BBLR sebanyak 26 orang $(65 \%)$, ibu dengan gizi kurang yang melahirkan bayi normal sebanyak 4 orang $(14,3 \%)$, ibu dengan status gizi baik yang melahirkan BBLR sebanyak 14 orang (35\%), dan ibu dengan status gizi baik yang melahirkan bayi normal sebanyak 24 orang $(85,7 \%)$.

Menurut Manuaba IBG (2010), kurang gizi selama kehamilan membuat nutrisi janin tidak tercukupi sehingga ibu yang kurang gizi cenderung melahirkan BBLR.

Harus dipahami bahwa seorang ibu yang sedang hamil, tidak hanya harus mencukupi kebutuhan gizi untuk dirinya saja melainkan untuk calon bayi yang tengah dikandungnya juga (DepKes RI, 2010). Hal ini juga sesuai dengan pendapat dr Prita (2010), yang mengatakan pertumbuhan janin sangat dipengaruhi oleh status gizi ibu, jika status gizi ibu buruk maka diwaspadai ibu tersebut akan melahirkan BBLR.

Dari hasil penelitian tersebut, peneliti berpendapat bahwa memang ada hubungan yang signifikan antara gizi pada ibu selama kehamilannya dengan berat badan lahir bayinya, hal tersebut karena kurangnya asupan gizi yang diperoleh bayi selama dalam kandungan, sehingga perkembangan dan pertumbuhannya terganggu dan cenderung lahir dengan berat badan lahir rendahPertumbuhan janin sangat dipengaruhi oleh status gizi ibu hamil sebelum kehamilan.Jika calon ibu memiliki asupan gizi yang cukup dan seimbang, maka akan melahirkan anak yang sehat. Untuk mencapai 
kondisi ideal ini,banyak yang merasa kesulitan dan bermasalah dengan pemenuhan kebutuhan gizi ini. Sampai saat ini masih banyak ibu hamil yang mengalami masalah gizi, khususnya gizi kurang seperti kurang energi kronis (KEK) dan anemia.Sehingga mempunyai kecenderungan melahirkan bayi dengan berat badan lahir rendah (DepKes RI, 2010).

Oleh sebab itu untuk masalah gizi kurang ini tidak hanya tugas dari tenaga kesehatan, namun juga pemerinttah harus turun tangan karena ternyata penyebab para ibu mengalami gizi kurang paling banyak adalah karena status ekonomi menengah kebawah.

\section{KESIMPULAN}

Berdasarkan hasil penelitian terhadap 68 responden di Medical Record RSUD AWS Samarinda pada bulan Januari tahun 2017, dapat disimpulkan bahwa :

1. Gizi Kurang Pada Ibu

Ibu yang mengalami gizi kurang selama kehamilan di RSUD AWS Samarinda bulan Januari sebanyak 44,1\% dari total sampel sebanyak 68 responden.

2. Kejadian BBLR

Bayi yang lahir dengan berat badan <2500 gram di RSUD AWS selama bulan Januari 2017 sebanyak 58,8\% dari total sampel sebanyak 68 responden.

3. Hubungan Antara Gizi Kurang Dengan Kejadian BBLR

Berdasarkan hasil penelitian, peneliti menemukan hubungan antara gizi kurang pada ibu selama kehamilan dengan kejadian BBLR di RSUD AWS
Samarinda di bulan Januari 2017, dengan presentasi cukup besar, yaitu dari 40 bayi yang lahir dengan berat badan <2500 gram, ada 26 bayi yang dilahirkan oleh ibu yang mengalami gizi kurang selama kehamilan. Hal ini sesuai pendapat Sunita (2009), kekurangan gizi pada ibu hamil berpengaruh terhadap berat badan bayi saat dilahirkan, ibu yang mengalami gizi kurang cenderung melahirkan BBLR.

\section{DAFTAR PUSTAKA}

Alimul, dkk. 2010. Teknik Analisa Data. Jakarta : Salemba Medika

Arikunto. 2006. Prosedur Penelitian Suatu Pendekatan Praktek. Jakarta: PT Rineka Cipta

Danang, dkk. 2011. Analisis Penelitian Kesehatan. Yogyakarta : Nuha Medika

Depkes RI. 2010. Survey Angka Kematian Ibu Dan Anak

Deslideldkk.2012. Ilmu Ajar: Asuhan Kebidanan Pada Bayi Baru Lahir. Jakarta : Salemba Medika

Dinas Kesehatan Kota Samarinda. 2014. Data BBLR tahun 2014. Samarinda : DKK

Laporan Tahunan. 2014. Laporan Tahunan Kejadian BBLR 4 Tahun Terakhir. Samarinda : RSUD AWS

Marmi dkk. 2013. Gizi Dalam Kesehatan Reproduksi. Jakarta : Pustaka Pelajar 
JURNAL KEBIDANAN MUTIARA MAHAKAM , VOLUME VI NOMOR 02, SEPETEMBER 2018

Manuaba IBG. 2010. Kecukupan Nutrisi

Pada Kehamilan. Jakarta : EGC

Sarwono dkk. 2010. Ilmu Kebidanan, Edisi

2010. Jakarta : yayasan Bina

Pustaka Sarwono Prawirohardjo

Sunita. 2009. Prinsip Dasar Ilmu Gizi.

Jakarta : PT. Gramedia Pustaka Utama

Suradi, dkk. 2010. Gizi Ibu Hamil.

Yogyakarta : Nuha Medika

Suyanto. 2009. Riset Kebidanan Metodologi

dan Aplikasi.Yogyakarta : Mitra

Cendikia Press

Wong. 2012. Penatalaksanaan BBLR. Jakarta : EGC

Yasmin, dkk. 2011. Buku Ajar : Antenatal

Care. Jakarta : Pustaka Pelajar 